\title{
Reproductive behaviour of wild-living wolves in Białowieża Primeval Forest
}

\section{(Poland)}

Krzysztof Schmidt, Włodzimierz Jędrzejewski, Jörn Theuerkauf, Rafał Kowalczyk, Henryk

Okarma and Bogumiła Jędrzejewska

K. Schmidt ${ }^{1}$, W. Jędrzejewski, (wjedrzej@zbs.bialowieza.pl), J. Theuerkauf ${ }^{2}$

(jtheuer@miiz.waw.pl). R. Kowalczyk (rkowal@zbs.bialowieza.pl), H. Okarma ${ }^{3}$

(okarma@iop.krakow.pl) and B.Jędrzejewska (bjedrzej@zbs.bialowieza.pl): Mammal

Research Institute, Polish Academy of Sciences, PL-17-230 Białowieża, Poland

${ }^{1}$ Corresponding author: Mammal Research Institute, Polish Academy of Sciences, PL-17-230

Białowieża, Poland, phone: (48) 85 6827777, fax: (48) 85 6812289,

e-mail: kschmidt@bison.zbs.bialowieza.pl

${ }^{2}$ present address: Carpathian Wildlife Research Station, Museum and Institute of Zoology, Polish Academy of Sciences, ul. Ogrodowa 10, PL-38-700 Ustrzyki Dolne, Poland ${ }^{3}$ present address: Institute of Nature Conservation, Polish Academy of Sciences, ul. Mickiewicza 33, PL-31-120 Kraków, Poland) 


\begin{abstract}
Schmidt K., Jędrzejewski W., Theuerkauf J., Kowalczyk R., Okarma H. and Jędrzejewska B. Reproductive behaviour of wild-living wolves in Białowieża Primeval Forest (Poland).
\end{abstract}

Characteristics of reproductive behaviour of wolves (Canis lupus) were studied by radiotracking and snow-tracking of four packs in Białowieża Primeval Forest (BPF), Poland, in 1995-1999. Signs of mating occurred between 12 January - 22 March. Parturitions took place between 19 April - 12 May, and the denning period lasted for 49-64 days. During that time, wolves utilised 1-3 den sites, spending on average 27 days in each site. The dens were never reused in consecutive years, but year after year the breeding sites were located in the same parts of the pack's territory. Pregnant females shrunk their normal mobility by half on 10 days before parturition (from 23 to $13.5 \mathrm{~km}$ per day, on average). During 10 days post partum, they spent $85 \%$ of time with pups and travelled $3.9 \mathrm{~km} /$ day, only. On days $11-30$ after parturition, females spent $74 \%$ of their time tending pups and increased their daily movement distance to a mean of $13.3 \mathrm{~km}$. The females resumed full mobility 50-70 days after parturition that coincides with termination of the weaning process. Anecdotal observations indicated that pups were tended by other pack members while the mother was absent. Compared to years 1947-1950, in 1995-1999 the breeding season of wolves in BPF occurred 2 weeks earlier. The possible reason was the warming of mean annual temperature by $1-1.5^{\circ} \mathrm{C}$ during the last 50 years.

Key words: Canis lupus, wolf, reproduction, denning, parental care 


\section{Introduction}

The basic social unit in a wolf Canis lupus population is a breeding pair with their offspring (Mech 1970, 1999). The wolves breed once a year, and periodicity of reproduction influences the social behaviour, movements, and structure of the pack (Packard 2003). The main phases in female reproduction (proestrus, estrus, and pup care; see Packard et al. 1983) received various amount of scientific consideration. Many studies have been conducted in captivity (see Packard 2003 for review). Information on wild wolves' reproductive biology is also available, though often based on anecdotal reports on specific aspects of the breeding behaviour from North America (e.g. Harrington and Mech 1982; Fuller 1989; Ballard et al. 1991; Boyd et al. 1993; Thiel et al. 1997) and the former Soviet Union (e.g. Makridin 1959; Fedosenko et al. 1978; Gursky 1978; Filimonov 1980; Vyrypaev and Vorobev 1983; Annenkov 1988). More comprehensive information on reproductive behaviour of wolves in the Voronezh region (the European part of Russia) was provided by Ryabov (1988).

A great majority of data collected by the Russian researchers (all papers cited above) and some of those reported by North American authors (e.g. Boertje and Stephenson 1992) come from wolf control programmes, so the detailed data on behaviour of free-ranging wolves during the breeding season are still limited. The information available to date is mostly based on presence-absence of wolves at the den or rendezvous sites recorded by visual observations (Murrie 1944, Mech 1988) or telemetry (e.g. Harrington and Mech 1982; Ballard et al. 1991).

The aim of this paper was to provide data on wolf behaviour in various phases of their reproductive cycle to increase our understanding of the biological potential of the species. The particular objectives of the study, conducted in Białowieża Primeval Forest, eastern Poland, were to characterise: (1) the timing of various phases of reproduction (from proestrus in females till the end of denning period of pups); (2) location and use of den sites in the same 
and consecutive years; and (3) movements and den attendance by the breeding females from the last weeks of pregnancy till the end of the denning period.

\section{Materials and methods}

\section{Study area}

The study was conducted in the Białowieża Primeval Forest (BPF) in Eastern Poland $\left(52^{\circ} 30^{\prime}-\right.$ $\left.53^{\circ} \mathrm{N}, 23^{\circ} 30^{\prime}-24^{\circ} 15^{\prime} \mathrm{E}\right)$. BPF is a temperate mixed lowland forest characterized by high percentage of natural stands. It straddles the Polish-Belarussian border and covers nearly 1500 $\mathrm{km}^{2}$. The Polish part of BPF, where the study was performed, covers $600 \mathrm{~km}^{2}$. About $80 \%$ of the Polish part is managed and exploited for timber by the State Forests, while the rest is protected as Białowieża National Park (BNP, $\left.100 \mathrm{~km}^{2}\right)$, which includes a strict reserve (47 $\mathrm{km}^{2}$ ) with limited human access. The climate of BPF has a transitional character between Atlantic and continental types with clearly marked warm and cold periods. Mean temperatures during the study period were $-3.9^{\circ} \mathrm{C}$ in January and $19.1{ }^{\circ} \mathrm{C}$ in July. Mean annual precipitation was $622 \mathrm{~mm}$, and snow cover persisted for an average of 96 days per year.

In BPF, wolves coexist with five species of wild ungulates: European bison Bison bonasus, moose Alces alces, red deer Cervus elaphus (dominant prey of wolves), roe deer Capreolus capreolus, and wild boar Sus scrofa (Jędrzejewski et al., 2002). The wolf is a protected species; the population in the Polish part of BPF is not legally exploited but some poaching does occur. In the Belarussian part of BPF, wolf numbers are controlled (Jędrzejewska et al. 1996). More information about Białowieża Forest and its wolf population is given by Jędrzejewska and Jędrzejewski (1998).

\section{Collecting data on wolf reproduction}

The study was conducted in 1995-1999 by means of radio-tracking and snow-tracking. The wolves were captured either with 'fladry' and nets (Okarma and Jędrzejewski 1997) or foot 
snare traps (equipped with alarm-system). Wolves were immobilized with a mixture of ketamine hydrochloride (3.4-4.5 mg/kg of body weight) and xylazine hydrochloride (5-6.5 $\mathrm{mg} / \mathrm{kg}$ of body weight). They were fitted with VHF radio-collars made by Telonics Inc., AVM Instrument Company, and Telemetry System. Data on 6 radio-collared females (5 breeding individuals and a non-breeding yearling) belonging to 4 packs were used for the analyses. The packs held territories covering 170-300 $\mathrm{km}^{2}$ (Okarma et al. 1998) and consisted of 2 to 8 individuals, though the number of wolves $>1$ year old varied from 2 to 5 per pack.

We located radio-collared wolves 2-5 times per week by triangulation from the forest roads. Additionally, each month we conducted sessions of continuous 24-h radio-tracking lasting 2-7 days, during which we located animals every 30 (in 1995-1996) or every 15 min (in 1997-1999). The distance between observers and wolves was, on average, $0.94 \mathrm{~km}$ and no detectable influence of observers on wolves' activity was found (Theuerkauf and Jędrzejewski 2002). The mean radio-tracking error was $194 \mathrm{~m}$ (95\% CI: 157-231 m) (Theuerkauf and Jędrzejewski 2002). For the purpose of this study, we used a total of 10,869 radio-locations, which included 105 sessions of continuous radio-tracking.

Based on repeated locations from the same area, den sites were searched after the wolves had left them. In 8 cases, we found the actual dens with signs of recent utilization by wolves, whereas in 7 cases the den sites were not found and their most probable locations were determined based on telemetry records (supposed dens).

We estimated the parturition dates based on changes in females' movements as determined by radio-tracking: repeated locations in the same place. In one case, visual observations of the female in obvious pregnancy and then after giving birth helped us to verify the birth date. In most cases, however, it was possible to determine not the exact date, but the most reliable range of parturition dates. For the analysis of females' mobility, the most probable date of parturition was taken as day 0 , and the following parameters of their activity were calculated: 
(1) Daily movement distance (DMD): the sum of straight-line distances between consecutive locations taken at 15 or 30 -min intervals during 24 -h radio-tracking. As in some radio-tracking sessions we temporarily lost contact with animals, we calculated the DMD based on at least 45 locations per day, when taken every 15 min, or at least 16 locations per day, when taken every 30 min. The mean number of locations for estimating DMD was 72 per day. Such criteria of data selection may thus somewhat underestimate the DMD compared to calculations based on data fully covering the 24-h sessions (as in Jędrzejewski et al. 2001). DMD was calculated for 50 days prior to and 90 days after parturition.

(2) Maximum straight-line distance of a female from the den: a straight-line distance between the den and the farthest location of the wolf during a given day. We calculated this parameter for 50 days before and 90 days after parturition based on all telemetry data available. The spatial analyses of wolves' locations were done with the program Tracker (Radio Location Systems AB, Huddinge, Sweden).

(3) Length of uninterrupted bouts the females were present in/at the den or absent from it. For this analysis, we selected the most complete data set of 24-h radio-tracking during the denning period. It includes 23 days between $19^{\text {th }}$ April to $22^{\text {nd }}$ June. All locations of radiotagged females that fell in a radius of $231 \mathrm{~m}$ (upper CI limit of location error) around the actual or supposed den were considered as locations in or at the den.

Based on preliminary assessment of data we distinguished a particularly significant period relative to the parturition: 0-10 days before and after birth, for further analysis. However, we divided the remaining period into 20 days intervals due to scarcity of data. We conducted $403.7 \mathrm{~km}$ of snow-tracking of radio-collared packs to record signs of proestrus (urination with bloody discharge; Kreeger 2003) and probable copulations (spots 2$10 \mathrm{~m}$ in diameter, densely trampled by wolves). The appearance of copulation places were confirmed by comparing tracks left by copulating captive wolves (courtesy of the private breeding centre of Mr J. and B. Walencik, Białowieża). 


\section{Results}

Estrus, parturition, denning period, and den sites

Urine markings with blood, as indicators of proestrus phase in female wolves, were recorded from 12 January till 22 March, with the highest frequency (on average, 0.72 per $1 \mathrm{~km}$ of trail) in February (Table 1). Signs of possible copulations, as read from tracks in snow, occurred between 13 January and 1 March (Table 1). However, as documented by life histories of radio-tracked females, only copulations that took place between 30 January and 1 March resulted in pregnancies. In one case (pack Białowieża National Park in 1999), the bloody vaginal discharge in urine markings and possible signs of copulations were seen during snow tracking in mid January and then again in late February. As indicated by the parturition date (19-23 April), matings observed in February resulted in pregnancy.

The mean number of wolves travelling together declined from 3.8-4.1 in NovemberDecember to 3.2 in March (Table 1). The breeding pair did not separate from other pack members for mating. In January- 1 March, signs of possible copulations were recorded on trails of 2-5 wolves moving together (mean 3.6, SE $0.2, n=29$ ), similarly to the trails with no signs of mating (2-5 wolves, mean 3.5, SE 0.2, $n=92$; Mann-Whitney $U$ test, $U=375, p=$ $0.98)$.

After pregnancy lasting $63 \pm 2$ days (Seal et al. 1979), parturitions $(n=11)$ occurred between 19 April and 12 May (Table 2). The denning period lasted from 49 to 64 days, that is 7-9 weeks (on average 58 days, SE 2) and during that time, wolves utilised from 1 to 3, on average 2.25 den sites (SE 0.25), spending on average 27 days (SE 4) in each den (Table 2). The longest utilization of single dens occurred in the strict reserve of the Białowieża National Park, where people had very limited access (49 days, female Chyża in 1999), and in the zone of state border with low human activity (62 days, female Siwa in 1998). 
Among the dens utilized and found during radio-tracking $(n=8)$ five were actual burrows dug out either by wolves or formerly by Eurasian badgers Meles meles or red foxes Vulpes vulpes. In three cases the lairs or shallow dens were localized under roots of uprooted trees (Table 2).

The dens utilized consecutively by a given female in the same year were located from 0.5 to $4.4 \mathrm{~km}$ from each other (Fig. 1). None of the females utilized the same den in consecutive years. The average distance (mean $\pm \mathrm{SE}$ ) among all dens utilized by the same female in various years was $2.4 \pm 0.25 \mathrm{~km}$ (from 0.4 to $5.2 \mathrm{~km} ; n=30$ ). We had also an opportunity to measure distances between dens utilized by two females belonging to the same pack. One of them (Ruda) was a mother of another (Chyża) (Jędrzejewski et al. 2005). Chyża gave birth to pups for the first time in a year following the death of Ruda (Table 2). On average, their den sites (Ruda: $n=4$; Chyża: $n=2$ ) were situated at a distance $2.8 \pm 0.4 \mathrm{~km}$ (from 0.3 to $5.9 \mathrm{~km}$ ) from each other. The den sites utilized by different neighbouring packs of wolves $(n=4)$ were located $11.9 \pm 1.4 \mathrm{~km}$ from each other (range: $7.2-15.5 \mathrm{~km})$.

\section{Behaviour of breeding females before and during denning}

On 50 to 30 days before parturition, the daily movement distance (DMD) covered by pregnant females was long (on average, $23 \mathrm{~km}$ ). It decreased by half (to $13.5 \mathrm{~km}$, on average) only for 10 days before parturition (Fig. 2). During the first 10 days post partum the breeding females travelled only $3.9 \mathrm{~km}$ per day. However, already on days 11-30 they resumed greater mobility, and two months after parturition (days 51-70 days) females' DMD averaged 19.4 $\mathrm{km}$. The variation in DMD of the breeding females in relation to parturition time was statistically different from a homogenous pattern (Kruskal-Wallis ANOVA, $H=37.1$, df $=7$, $p<0.001)$.

DMD alone does not show a complete picture of females' mobility. Another parameter that changed markedly was their longest straight-line distance from the breeding den while 
travelling (Fig. 3). On 50-10 days before parturition, pregnant females moved within a mean radius of 5.3-5.5 km around the den. On the last 10 days before giving births, that distance declined to a mean of $3.7 \mathrm{~km}$, and the females were for the first time located at the den site to be occupied. Maximum straight-line distances of the females from their dens were shortest during 10 days post partum (on average, $0.9 \mathrm{~km}$ ). Interestingly, although their DMD increased already on 11-30 days after parturition, the breeding females restricted their movements to the vicinities of a den with pups, as their maximum straight-line distance from the den averaged $1.2 \mathrm{~km}$ (Fig. 3). It was only during the second month of pups' life (days 3150 post partum), that females began to depart farther from the den. Two months after giving births, females resumed as far exploration of the pack's territory as before parturition (Fig. 3).

The duration of time the females spent in or at the den averaged $62 \%$ of the daytime (i.e. of 24-h periods) during 10 days before parturition, and it increased to $85 \%$ during 10 days after it (Fig. 4). Later on the proportion of time spend at the nest declined slightly to $74 \%$ on days $11-30$ and $65 \%$ on days $31-50$ post partum (Fig. 4). The temporal changes in den attendance by females were marginally insignificant (Kruskal-Wallis ANOVA, $H=6.9$, df= $3, p=0.07$ ). During the pup rearing period, females were absent from the den for $15-34 \%$ of time.

Single bouts of females' staying in or at the den increased from an average of $3.2 \mathrm{~h}$ on 10 days before parturition to $11.7 \mathrm{~h}$ on the first 10 days of pups' life, and then declined to 7.2 and 6.6 h, respectively, on days 11-30 and 31-50 after parturition (Fig. 4). Variation in the duration of bouts females stayed in or at the den in relation to parturition time was statistically different from homogeneity (Kruskal-Wallis ANOVA, $H=12.5, \mathrm{df}=3, p<0.001$ ).

\section{Den attendance by two female wolves}

In 1997, two individuals, a breeding female Ruda, and her one-year-old daughter Chytra (as determined by genetic analysis; Jędrzejewski et al. 2005) were radio-tagged in the BNP pack, 
which then consisted of a breeding pair, 2 subadult females, and 3 pups. Between $15^{\text {th }}$ and $21^{\text {st }}$ June 1997, when pups were approximately 1.5 months old, we continuously radio-tracked those two females (Fig. 5). The records of both females covered $126 \mathrm{~h}$, that is $75 \%$ of the whole tracking period. During that time, the mother (Ruda) spent $74 \%$ of her time at the den with pups. Chytra stayed at the den for $23 \%$ of time, and during $17 \%$ of time neither of the two females were located at the den (note that two other wolves were not radio-tagged). In the total time, when pups were attended by at least one of the radio-collared females $(83 \%$ of daytime), Ruda alone was present there for $60 \%$ of time, Chytra alone for $8 \%$, and both of them for $15 \%$. On one day (20 June) we recorded apparent shifts in den attendance by Ruda and Chytra (Fig. 5).

\section{Discussion}

In North America, breeding dates of wolves depend on latitude. On average, reproductive season shifts 22 days later with each $10^{\circ}$ latitude increase (Mech 1986). Similarly, breeding season of the wolves in Palaearctic varies with latitude and altitude: the more severe is the climate, the later it occurs. In south-western Ukraine (near the Black Sea), proestrus and estrus in females were recorded between 10 January - 20 February, and parturitions were recorded in late March - mid April (Gursky 1978). In Kazakhstan, in the montane zone parturitions took place in late April, whereas in plains 1-2 weeks earlier (Annenkov 1988). In the Voronezh region (European part of Russia, latitude $52^{\circ} \mathrm{N}$ ), matings occurred between 8 February -17 March, with a peak (58\% of records) in the second half of February. Parturitions were recorded between 7 April - 20 May, with a majority of cases in the second half of April (47\%) and the first half of May (37\%) (Ryabov 1988). The latest breeding season was found in the tundra of Nenets region (northern Russia): necropsies of shot wolves evidenced that estrus occurred in March - April (Makridin 1959), thus pups were born in May - June. Our data from BPF located at $52-53^{\circ} \mathrm{N}$, with copulations recorded mostly in February 
and parturitions between 19 April - 12 May, fit well to this geographic pattern. Interestingly, the study conducted in the Belarussian part of BPF in 1947-1950, documented that copulations in wolves occurred in early March and parturitions between 4-21 May (Gavrin and Donaurov 1954) that is about 2 weeks later than in 1995-1999. The possible reason for earlier breeding season of wolves in recent years is the warming of climate: during the last 50 years, the mean annual temperature in $\mathrm{BPF}$ increased from $6.5^{\circ} \mathrm{C}$ to $7.5-8^{\circ} \mathrm{C}$ (Jędrzejewska and Jędrzejewski 1998).

Our earlier analyses (Jędrzejewski et al. 2001) evidenced that during the mating period (January - March) adult wolves became very mobile, travelling markedly longer daily distances $(26.2-26.6 \mathrm{~km})$ compared to the annual mean value $(22.8 \mathrm{~km})$. They also marked their territory more during that time: intensity of ground scratching was highest in January, and urine marking in February (Zub et al. 2003). Duration of wolves' daily activity peaked during the mating season (February-March) and then again in August, when pups began to travel with other pack members (Theuerkauf et al. 2003a). Contrary to older opinions (e.g. Gursky 1978), in BPF there was no increase in the vocal activity of wolves related to the mating period; in January - March wolves howled rarely compared to summer and early autumn months (Nowak et al. 2006).

In BPF, wolves avoided reusing dens in consecutive years and usually utilized more than one den during a single breeding season. The minimum time the female wolf could be expected to use the natal den is between 3-5 weeks, until the pups are mobile enough to explore its entrance (Packard 2003). The actual duration of using a single den or nest varied from 11 days to 2 months in north-central Minnesota (Fuller 1989) and to 3-4 months in Minnesota and south-central Alaska (Harrington and Mech 1982; Ballard et al. 1987). Reusing dens for several years (Ballard and Dau 1983; Fuller 1989) or even centuries (Mech and Packard 1990) by wolves is a well known phenomenon in North America. It was also 
reported from the tundra zone in northern Russia, where places suitable for den location are in shortage (Makridin 1959).

It has been shown by Thiel et al. (1998) that wolves may tolerate humans close to the dens as a response to protection. However, it seems that wolves in Central and Eastern Europe are very sensitive to human disturbance during the denning period in result of long-lasting persecution, in particular in the form of taking pups from the den (Jędrzejewska et al. 1996). That was probably also the reason that wolves in our area were never found to use particular dens more than once and they usually moved pups to the second and occasionally the third den or nest. Theuerkauf et al. (2003b) documented that, in BPF, wolves avoided both humans, who were present in forest more frequently in summer than in winter, and human-made structures such as settlements and roads.

Filimonov (1980) reported that, in Kazakhstan, wolves moved their pups in response to human disturbance to a new den sites located 4 and $9 \mathrm{~km}$ away from the natal den. In the steppe-forest and steppe zone of Ukraine and Moldova, wolves frequently carried pups to new sites in May-June in response to human presence associated with mowing grass and haymaking on wood meadows near the natal dens (Gursky 1978). In the Voronezh region, Russia, Ryabov (1988) reported shifts to new den sites located 0.4-6 km away from the natal dens, again in response to human disturbance. Wolves can also move pups for natural reasons, such as drying out the only source of drinking water nearby, as observed in the Tien-Shan Mountains, Kazakhstan (Fedosenko et al. 1978).

Despite frequent changes of denning sites during a single pup rearing season, Eurasian wolves seem conservative in using the same part of their territory for locating nests year after year (Gursky 1978; this study). In BPF, wolf den sites were located in relatively quiet, remote places, at greater distances from villages, forest edges, and intensively used roads than expected at random (Theuerkauf et al. 2003c). Ciucci and Mech (1992) suggested that location of wolves' dens tend to be random relative to the territory center, though it can be 
more central in large territories. Our wolves had rather small territories (Jędrzejewski et al. 2007) and their dens seemed to be located centrally. This is, however, in accordance with observations by Zub et al. (2003) showing that wolves in BPF concentrate their scent-marking activity in the central zones of the territories surrounding the dens as a response to potential agonistic encounters with neighboring packs. The central location of the den may thus increase security of the denning area.

In Eurasia, types of wolf breeding sites were determined by local physiographic and soil conditions, and included dens dug by wolves themselves, setts of badgers and burrows of red foxes, nests on the ground in dense bushes, under tree roots or fallen trees, and - in the mountains - caves and rock crevices (Filimonov 1980; Vyrypaev and Vorobev 1983; Annenkov 1988; Ryabov 1988; this study). A particularly convenient opportunity for Eurasian wolves is the use of badger setts, which are large, deep, and located in well-drained soils. Wolves usually adapt the sett by enlarging one or two entrances. Wolf litters reared in old badger setts were reported from Kyrgyzstan (Vyrypaev and Vorobev, 1983), Kazakhstan (Annenkov 1988), Russia (Ryabov 1988), and Poland (this study). In the Voronezh region (central Russian), one-third of all nest sites of wolves were located in old badger setts (Ryabov 1988).

Based on time the females spent at the den sites, Ballard et al. (1991) reported that, in south-central Alaska, the breeding females of smaller packs - forced to participate in obtaining and providing food for pups - started exploring further areas from the den site earlier than those from larger packs. Ryabov (1988) reported that, in central Russia, breeding female began to hunt on the 10th-15th days after parturition. Pulliainen (1965) reported that during the early phases of denning period, breeding females hunted within a radius of $2 \mathrm{~km}$ around a den site. In BPF, despite the fact that breeding females increased their mobility already on 11-20 days after parturition, they moved (and possibly hunted) not far from the den site to be able to return to the pups for nursing. Until the pups are 7 weeks old, the interval 
between suckling bouts may not be longer than 5 hours (Packard et al. 1992). It was only 5170 days post partum, i.e. at the end of the denning period that the female resumed longdistance travels. Pups' age of 70 days means termination of the weaning process (Packard et al. 1992). Young began to follow adults in hunting and the kill sites may be used as temporary rendezvous sites for pups (Gray 1993).

Harrington and Mech (1982) and Ballard et al. (1991) have shown that, in Minnesota and Alaska, USA, pups before weaning were left unattended by breeding females for only 2$20 \%$ of time. In comparison to those regions, in BPF the breeding females were leaving pups for relatively long time during a day in the course of their first month of life (15-35\% of time, on average). It raises a question whether other pack members assisted in tending pups when a breeding female was away. Both Harrington and Mech (1982) and Ballard et al. (1991) suggested that rather than tending pups, the yearlings stay at the den to beg for food from adults. However, Mech et al. (1999) have recently proved that auxiliary wolves may actually contribute food for pups more than compete for it. Based on observations of wolves in Yellowstone National Park, USA, Thurston (2002) documented that non-breeding members of packs (both females and males) provided substantial care for pups by attending the homesites, playing with, watching, following, and regurgitating to pups. Parents tended to be at the homesite more during the first month of pups' life, whereas alloparents (helpers) were present more later on. Our study provided an anecdotal report on den attendance by a yearling female in one pack. Furthermore, our earlier analysis of mobility of wolves in BPF (Jędrzejewski et al. 2001) also suggested that subadult non-breeding females provided care for pups, as their daily movements during the denning period (on average, 4.3-8.6 km per day in May-June) were even shorter than those of adult breeding females (5-15.7 km). It was probably the adult male that did most of the hunting to provide food, as his daily movements were rather long (on average, $25.7 \mathrm{~km}$ in May). Thus, our findings correspond to the conclusion by Mech (1999) that in a typical wolf pack, adult parents guide the activities of the 
pack in a division-of-labour system, in which the female predominates in pup care and defense, whereas the male in food-provisioning and hunting travels.

\section{Acknowledgements:}

This study was financed by the budget of Mammal Research Institute PAS, the Polish State Committee for Scientific Research (grants 6P20401905 and 6P04F02612), the European Natural Heritage Fund (Euronature, Germany), the German Academic Exchange Service (to JT), and the German Doner's Association for the Promotion of Sciences and Humanities (to

JT).We thank S. Śnieżko, R. Kozak, I. Ruczyński, M. Chudziński, P. Wasiak, S. Rouys and R. Gula, as well as numerous students and volunteers, who helped during the field work. Permission to capture and radio-collar wolves were issued by Ministry of Forestry and Nature Protection and the Director of Białowieża National Park.

\section{References}

Annenkov BP (1988) The wolf in the Alakolsk Valley. Akademiya Nauk Kazakhskoi SSR, Trudy Instituta Zoologii 44:69-73 [in Russian]

Ballard WB, Whitman JS, Gardner CL (1987) Ecology of an exploited wolf population in south-central Alaska. Wildl Monogr 98:1-54

Ballard WB, Dau JR (1983) Characteristic of gray wolf, Canis lupus, den and rendez-vous sites in southcentral Alaska. Can Field-Nat 97:299-302

Ballard WB, Ayres LA, Gardner CL, Foster JW (1991) Den site activity patterns of gray wolves, Canis lupus, in southcentral Alaska. Can Field-Nat 105:497-504

Boertje RD, Stephenson RO (1992) Effects of ungulate availability on wolf reproductive potential in Alaska. Can J Zool 70:2441-2443 
Boyd DK, Ream RR, Pletscher DH, Fairchild MW (1993) Variation in denning and parturition dates of a wild gray wolf, Canis lupus, in the Rocky Mountains. Can FieldNat 107:359-360

Ciucci P and Mech LD (1992) Selection of wolf dens in relation to winter territories in northeastern Minnesota. J Mamm 73:899-905.

Fedosenko AK, Zhiryakov VA, Grachev YA (1978) Some data on the ecology and behavior of wolves in the Northern Tien-Shan and Dzungara Alatau. Byull Mosk Obshch Ispyt Prirody, Otd Biol 83(3):5-18 [in Russian with English summary]

Filimonov AN (1980) Behaviour of the Kazakhstan wolves in various situations. In: Bibikov DI (ed) Behaviour of wolves. Institut Evolucionnoi Morfologii i Ekologii Zhivotnykh, Akademiya Nauk SSSR, Moskva, pp. 60-76 [in Russian]

Fuller TK (1989) Denning behavior of wolves in north-central Minnesota. Am Midl Nat $121: 184-188$

Gavrin VF, Donaurov SS (1954) The wolf in Białowieża Primeval Forest. Zool Zhurn 33:904-924 [in Russian]

Gray DR (1993) The use of muskox kill sites as temporary rendezvous sites by artic wolves with pups in early winter. Arctic 46:324-330

Gursky IG (1978) The wolf in the northwestern Black Sea region (habitats, structure of populations, reproduction). Byull Mosk Obshch Ispyt Prirody, Otd Biol 83(3):29-38 [in Russian with English summary]

Harrington FH, Mech LD (1982) Patterns of homesite attendance in two Minnesota wolf packs. In: Harrington FH, Paquet PC (eds) Wolves of the world. Noyes Publications, New Jersey, pp. 81-105

Jędrzejewska B, Jędrzejewski W (1998) Predation in vertebrate communities. The Białowieża Primeval Forest as a case study. Springer, Berlin Heidelberg New York 
Jędrzejewska B, Jędrzejewski W, Bunevich AN, Miłkowski L, Okarma H (1996) Population dynamics of wolves Canis lupus in Białowieża Primeval Forest (Poland and Belarus) in relation to hunting by humans, 1847-1993. Mammal Rev 26:103-126

Jędrzejewski W, Schmidt K, Theuerkauf J, Jędrzejewska B, Okarma H (2001) Daily movements and territory use by radio-collared wolves, (Canis lupus) in Białowieża Primeval Forest in Poland. Can J Zool 79:1993-2004; doi:10.1139/cjz-79-11-1993 Jędrzejewski W, Schmidt K, Theuerkauf J, Jędrzejewska B, Selva N, Zub K, Szymura L (2002) Kill rates and predation by wolves on ungulate populations in Białowieża Primeval Forest (Poland). Ecology 83:1341-1356

Jędrzejewski W, Branicki W, Veit C, Medugorac I, Pilot M, Bunevich AN, Jędrzejewska B, Schmidt K, Theuerkauf J, Okarma H, Gula R, Szymura L, Förster M (2005) Genetic diversity and relatedness within packs in an intensely hunted population of wolves Canis lupus. Acta Theriol 50:3-22

Jędrzejewski W, Schmidt K, Theuerkauf J, Jędrzejewska B, Kowalczyk R (2007) Territory size of wolves Canis lupus: linking local (Bialowieza Primeval Forest, Poland) and Holarctic-scale patterns. Ecography (in press)

Kreeger TJ (2003) The internal wolf: physiology, pathology, and pharmacology. In: Mech LD, Boitani L (eds) Wolves: behavior, ecology and conservation. The University of Chicago Press, Chicago, pp. 192-217

Makridin VP (1959) Materials on the biology of wolf in tundra of the Nenets national region. Zool Zhurn 38:1719-1728 [in Russian with English summary]

Mech LD (1970) The wolf: the ecology and behavior of an endangered species. Natural History Press, Garden City, New York

Mech (LD) (1999) Alpha status, dominance, and division of labor in wolf packs. Can J Zool 77:1196-1203; doi: 10.1139/cjz-77-8-1196 
Mech LD (2002) Breeding season of wolves, Canis lupus, in relation to latitude. Can FieldNat 116:139-140

Mech LD, Packard JM (1990) Possible use of wolf, (Canis lupus), den over several centuries. Can Field-Nat 104:484-485

Mech LD (1988) The Arctic Wolf: Living With the Pack. Voyageur Press, Stillwater, MN Mech LD, Wolf PC, Packard JM (1999). Regurgitative food transfer among wild wolves. Can J Zool 77: 1192-1195; doi: 10.1139/cjz-77-8-1192

Murrie A (1944) The wolves of Mount McKinley. Fauna of the National Parks of the United States. Fauna Ser. 5, Washington D.C.

Nowak S, Jędrzejewski W, Schmidt K, Theuerkauf J, Mysłajek RW, Jędrzejewska B 2006. Howling activity of free-ranging wolves (Canis lupus) in the Białowieża Primeval Forest and the Western Beskidy Mountains (Poland). J Ethol doi: 10.1007/s10164-006$0015-\mathrm{y}$

Okarma H, Jędrzejewski W (1997) Livetrapping wolves with nets. Wildl Soc Bull 25:78-82

Okarma H, Jędrzejewski W, Schmidt K, Śnieżko S, Bunevich AN, Jędrzejewska B (1998) Home ranges of wolves in Białowieża Primeval Forest, Poland, compared with other Eurasian populations. J Mamm 79:842-852

Packard JM (2003) Wolf behavior: reproductive, social, and intelligent. In: Mech LD, Boitani L (eds) Wolves: behavior, ecology and conservation. The University of Chicago Press, Chicago, pp. 35-65

Packard JM, Mech LD, Seal US (1983) Social influences on reproduction in wolves. In:

Carbyn LN (ed) Wolves in Canada and Alaska: their status, biology, and management. Report Series, no 45. Canadian Wildlife Service, Edmonton Alberta, pp. 78-85

Packard JM, Mech LD, Ream RR (1992) Weaning in an arctic wolf pack: behavioural mechanisms. Can J Zool 70:1269-1275 
Peterson RO (1977) Wolf ecology and prey relationships on Isle Royale. Natl. Park Serv.

Monogr. Ser., no 11. Washington D.C.

Pulliainen E (1965) Studies on the wolf (Canis lupus L.) in Finland. Ann Zool Fenn 2:215259

Ryabov LS (1988) Characteristics of wolves' (Canis lupus L.) reproduction in the Central Black Earth Region. Ekologiya 6:42-48 [in Russian]

Seal US, Plotka ED, Packard JM, Mech, LD (1979) Endocrine correlates of reproduction in the wolf. I. Serum progesterone, estradiol and LH during the estrous cycle. Biol Reprod $21: 1057-1066$

Theuerkauf J, Jędrzejewski W (2002) Accuracy of radiotelemetry to estimate wolf activity and locations. J Wildl Manage 66:859-864

Theuerkauf J, Jędrzejewski W, Schmidt K, Okarma H, Ruczyński I, Śnieżko S, Gula R (2003a) Daily patterns and duration of wolf activity in the Białowieża Forest, Poland. J Mamm 84:243-253; doi: 10.1644/1545-1542(2003)084<0243:DPADOW>2.0.CO;2

Theuerkauf J, Jędrzejewski W, Schmidt K, Gula R (2003b) Spatiotemporal segregation of wolves from humans in the Białowieża Forest (Poland). J Wildl Manage 67:706-716

Theuerkauf J, Rouys S, Jędrzejewski W (2003c). Selection of den, rendezvous, and resting sites by wolves in the Białowieża Forest, Poland. Can J Zool 81:163-167; doi: $10.1139 / \mathrm{z} 02-190$

Thiel RP, Haller WH, Schultz RN (1997) Early den digging by wolves, Canis lupus, in Wisconsin. Can Field-Nat 111:481-482

Thiel RP, Merril S, Mech LD (1998) Tolerance by denning wolves, Canis lupus, to human disturbance. Can Field-Nat 112:340-342

Thurston LM (2002) Homesite attendance as a measure of alloparental and parental care by gray wolves (Canis lupus) in Northern Yellowstone National Park. MSc thesis, Texas A and M University, USA 
Vyrypaev VA, Vorobev GG (1983) The wolf in Kirgistan - ecological and geographic description. Izdatelstvo Ilim, Frunze [in Russian]

Zub K, Theuerkauf J, Jędrzejewski W, Jędrzejewska B, Schmidt K, Kowalczyk R. (2003) Wolf pack territory marking in the Białowieża Primeval Forest (Poland). Behaviour 140:635-648; doi: 10.1163/156853903322149478 
Table 1. Signs of heat in wolves (Canis lupus) as observed during snow tracking in Białowieża Primeval Forest, Poland, in 1996-1999

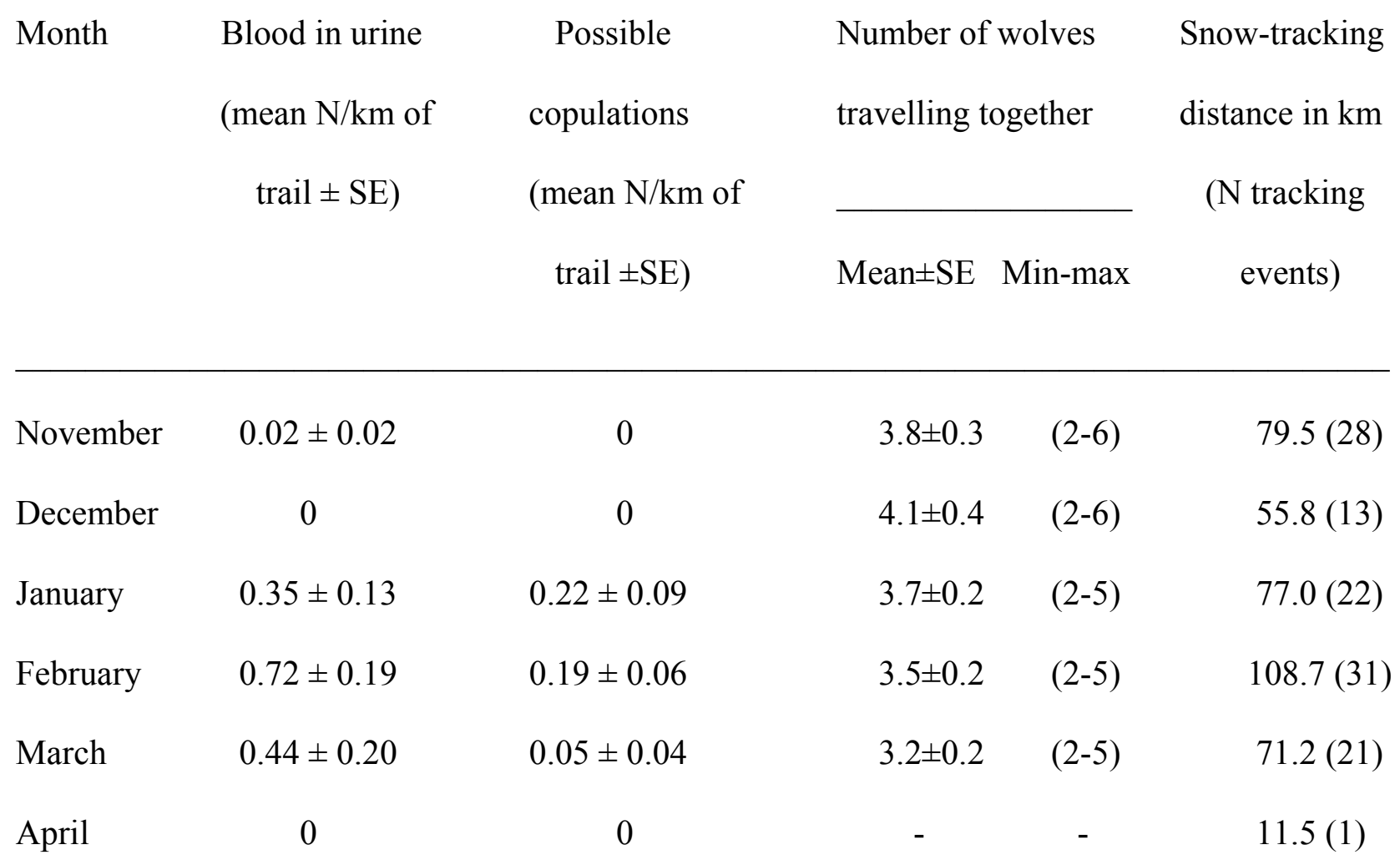


Table 2. Parturition dates and denning by radio-collared female wolves in BPF. Numbers in parentheses denote litters lost (females Ruda and Chyża) or dead breeding female (Sroga) found after a given number of days. Pluses mark the records of utilisation of dens but no data available on the period of their use. BNP = Białowieża National Park

Pack Female Most probable Minimum number of days spent at:

parturition date

$$
1^{\text {st }} \text { den } \quad 2^{\text {nd }} \text { den } \quad 3^{\text {rd }} \text { den } \quad \text { All dens }
$$

BNP

Ruda 28 Apr - 1 May '95

$$
20 \text { Apr - } 8 \text { May '96 }
$$

17

29 Apr - 5 May '97

10

$43^{\mathrm{e}}$

Chyża

2 May '98

$$
\text { 19-23 Apr '99 }
$$

$49^{\mathrm{f}}$

6

Leśna I

Bura

29 Apr - 5 May '95

26

23

$$
\text { Before } 8 \text { May '96 }
$$

$21^{\mathrm{a}}$

43

29 Apr - 5 May ‘97

15

$14^{\mathrm{b}}$

60

Leśna II Siwa

3-9 May '98

62

62

Ladzka

Sroga

7 May ‘98

$27^{\mathrm{g}}$

$+$

$-$

?

7-12 May '99

$(26)^{\mathrm{h}}$

${ }^{\mathrm{a}}$ Den in an old badger sett, 2 of 6 entrances enlarged by wolves.

${ }^{\mathrm{b}}$ Den in an old fox burrow, one of 2 entrances enlarged by wolves.

${ }^{\mathrm{c}}$ Single burrow dug by wolves in a sandy slope of a small hill.

${ }^{\mathrm{d}}$ Lairs under fallen, uprooted trees, near the root plate.

${ }^{\mathrm{e}, \mathrm{f}}$ Den in an old badger sett, one entrance enlarged by wolves.

${ }^{\mathrm{g}, \mathrm{h}}$ Den in a hollow under a root system of a fallen, uprooted tree. In that place, many windfallen trees pushed together by a bulldozer. 
Figure captions:

Fig. 1. Locations of den sites in the territories of wolf (Canis lupus) packs in Białowieża Primeval Forest, Poland, in 1996-1999. BNP - Białowieża National Park pack.

Fig. 2. Changes in daily movement distances (DMD, mean $\pm \mathrm{SE})$ covered by female wolves in relation to parturition date (day 0), based on data for 5 radio-collared females and 105 sessions of continuous 24-h radio-tracking. Numbers in the graph show the sample sizes for each time interval.

Fig. 3. Changes in the maximum straight-line distance (mean $\pm \mathrm{SE}$ ) of the female wolves from their den sites in relation to parturition date, based on radio-tracking of 5 females (396 days of radio-locations, including 105 sessions of continuous 24-h radio-tracking). Numbers in the graph show the sample sizes for each time interval.

Fig. 4. Duration of time the female wolves spent in/at the den site and away from it in relation to parturition date, based on 24-h sessions of continuous radio-tracking. Upper graph: percentage of time per $24 \mathrm{~h}($ mean $\pm \mathrm{SE})$ the females were present in/at and absent from the den sites. Lower graph: duration of single bouts (mean $\pm \mathrm{SE}$ ) of female's presence in/at and absence from the den site. Numbers in the graph show the sample sizes for each time interval.

Fig. 5. Pattern of tending pups at the den by two wolves from BNP pack: the breeding female Ruda (R, pups' mother) and a yearling female Chytra (C, pups' older sister) during 7 days (15-21 June 1997) of the denning period. Based on 24-h sessions of continuous radiotracking with locations taken at 15 -min intervals. 


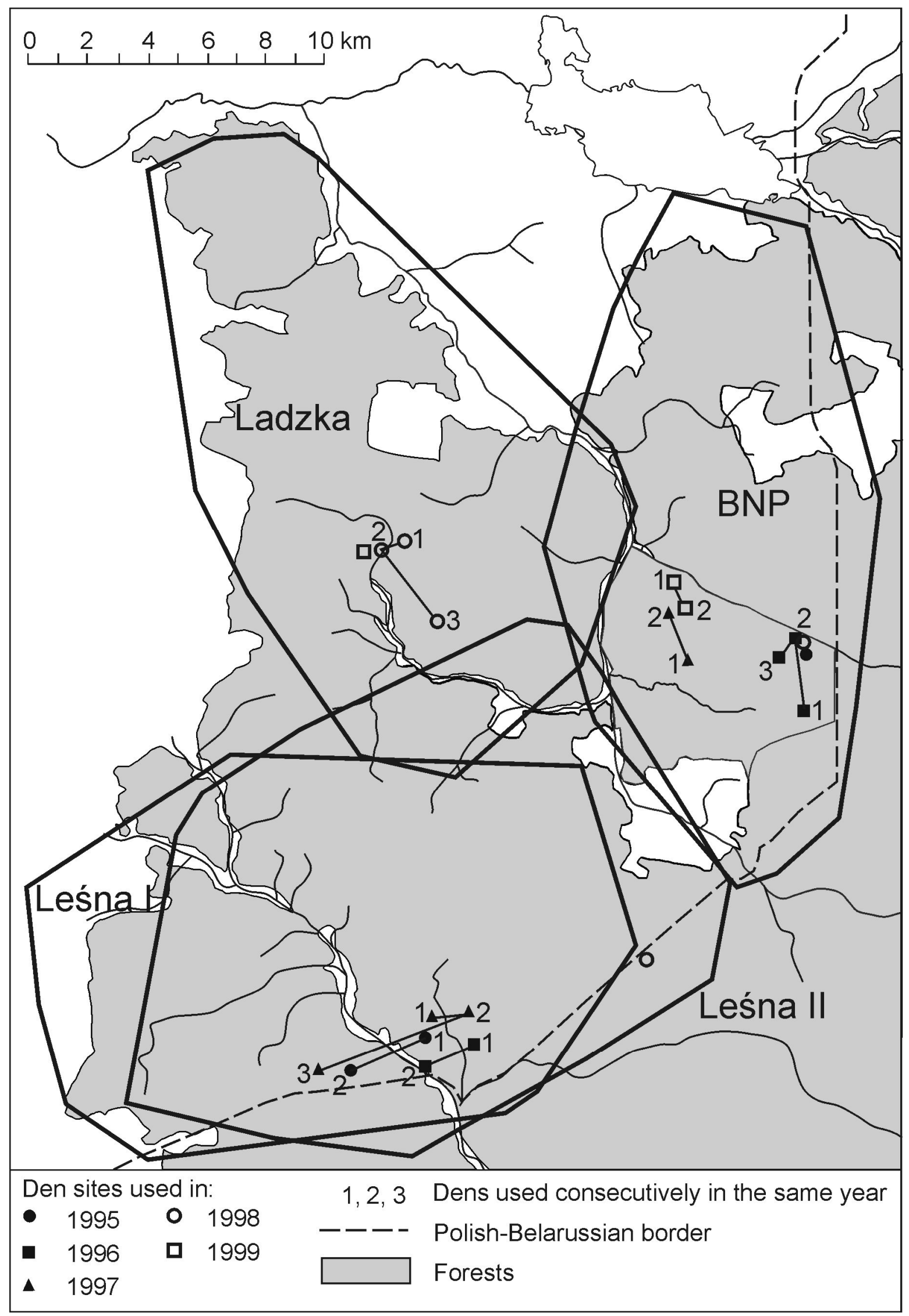

Fig. 1 


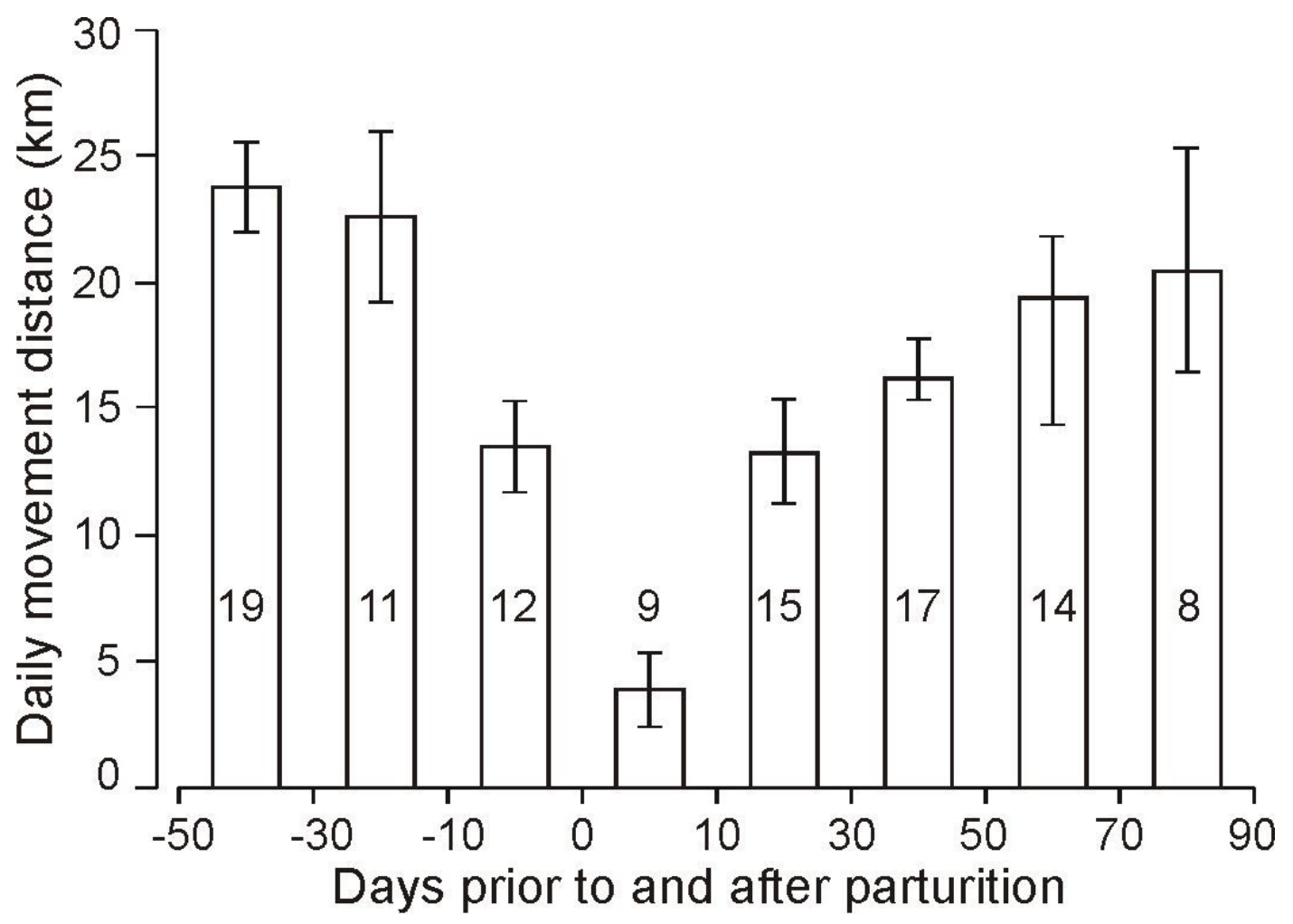

Fig. 2 


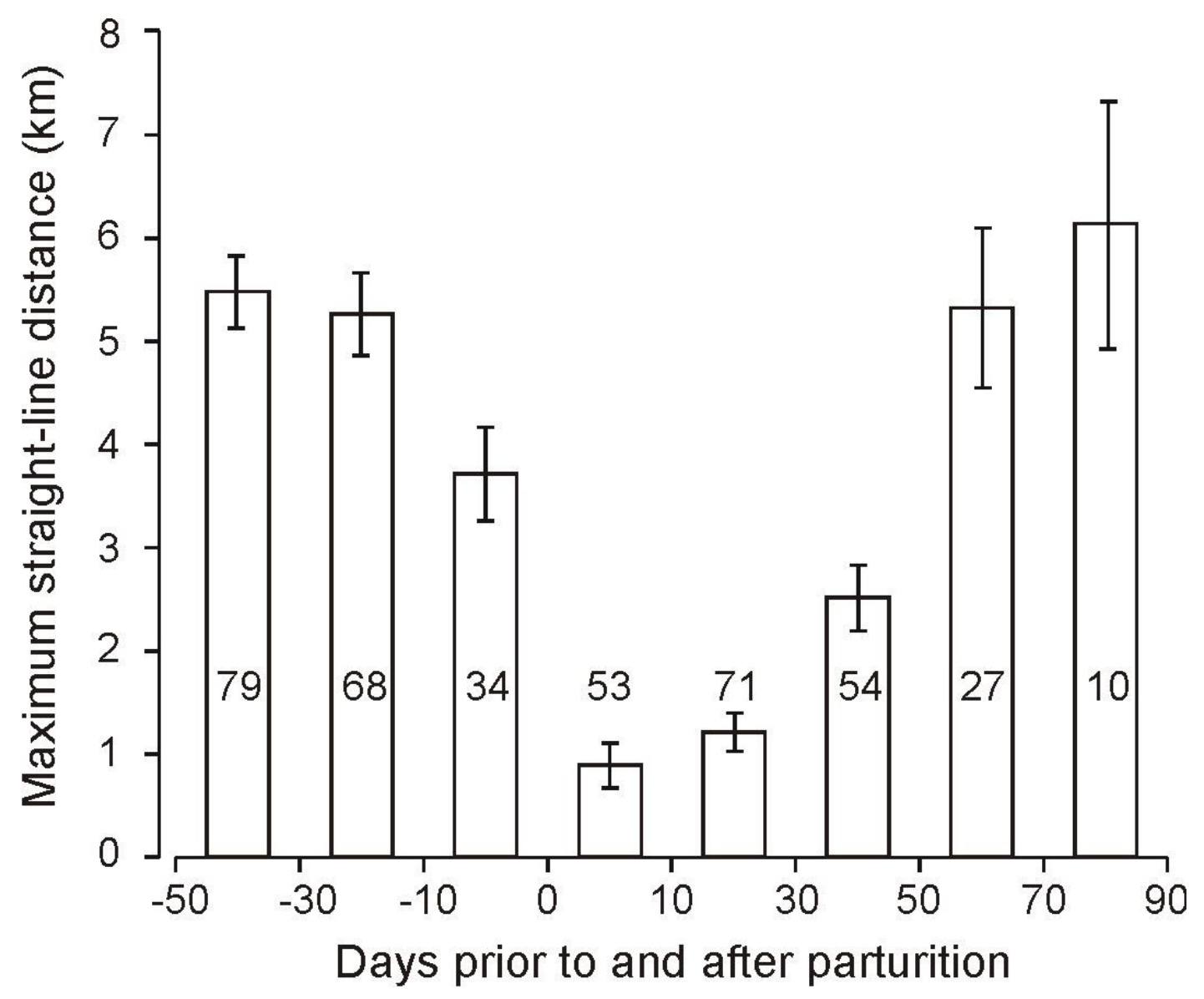

Fig. 3 

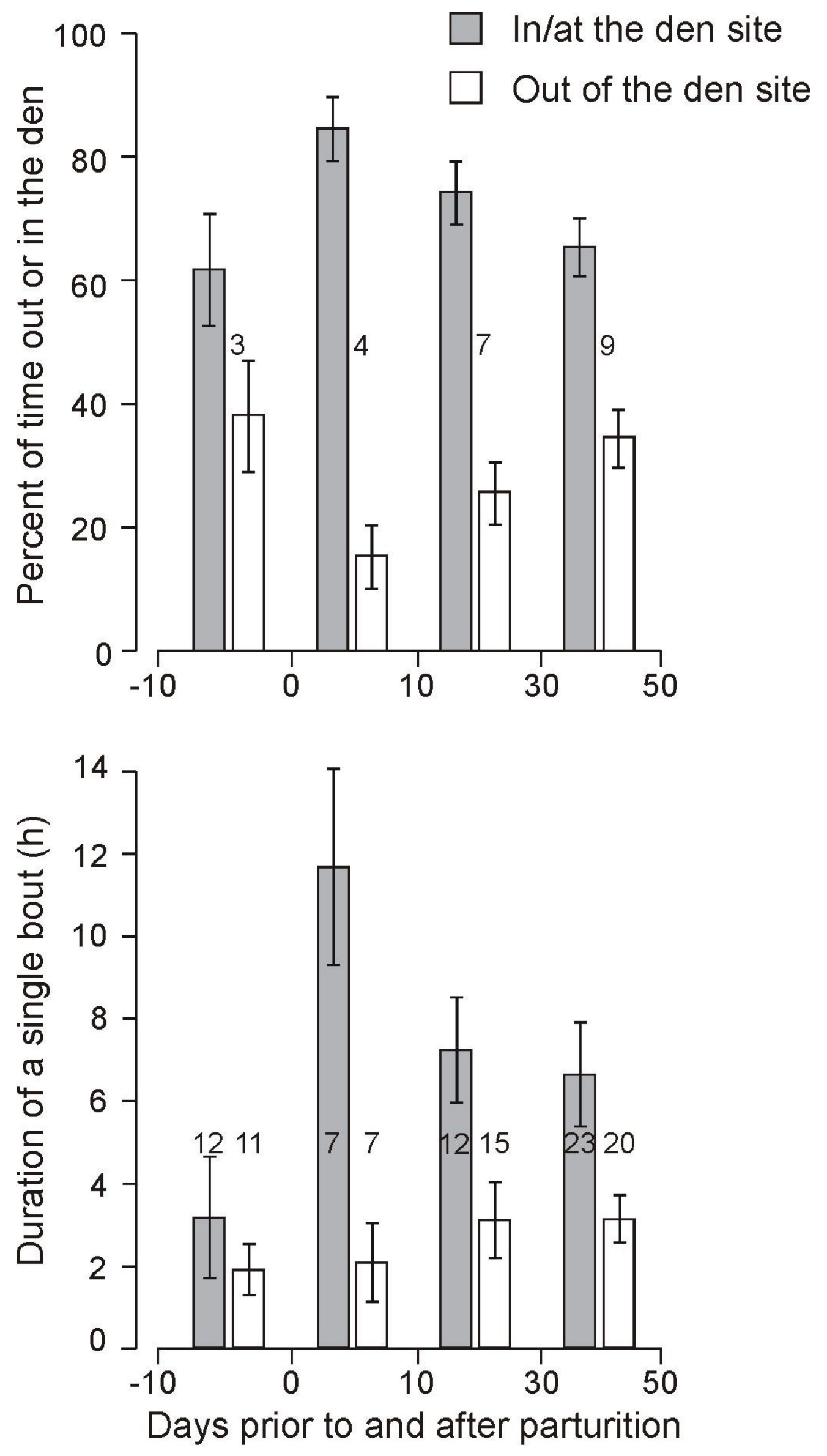

Fig. 4 


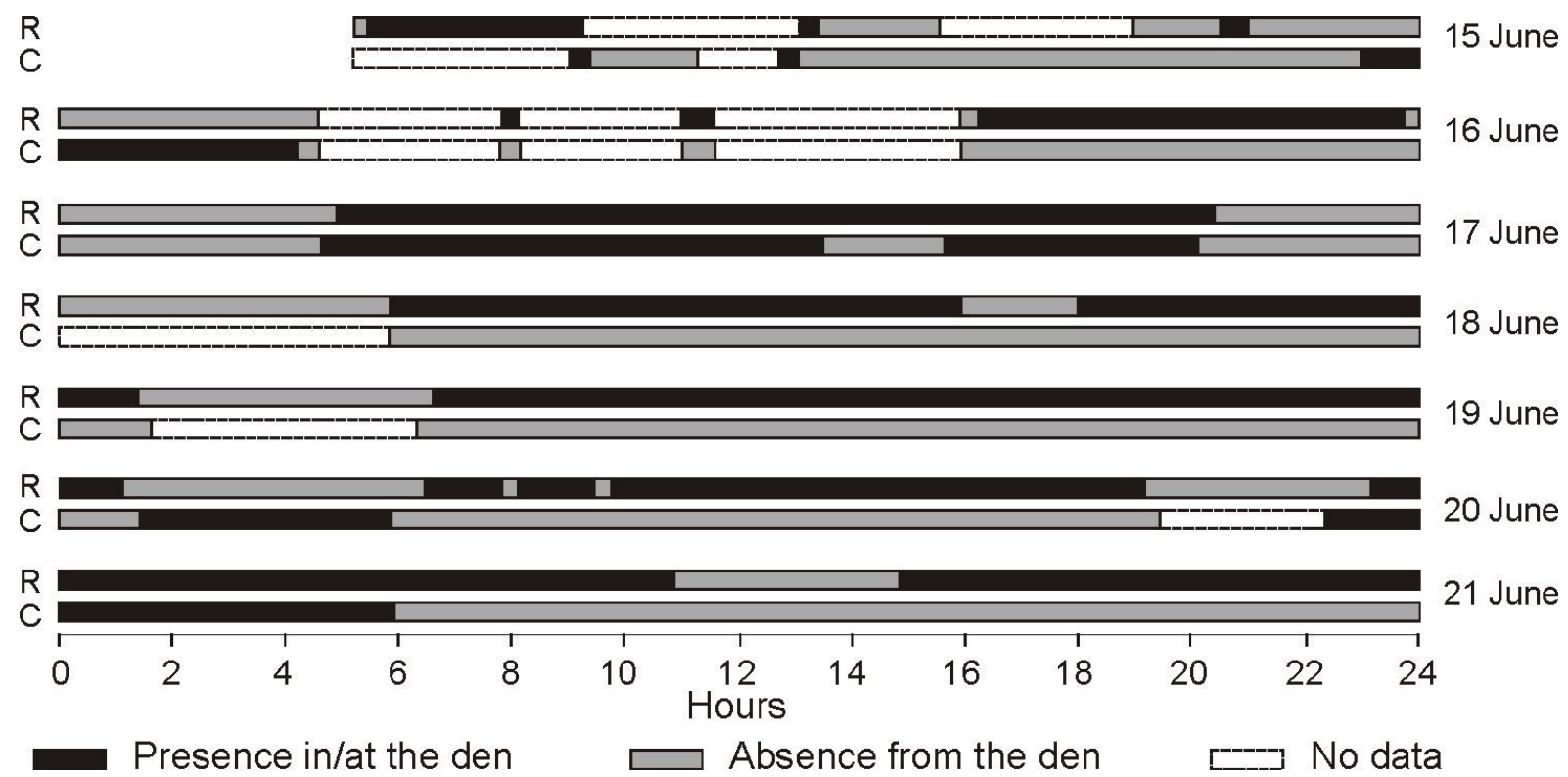

Fig. 5 